\title{
Effect of Goji Berries and Honey on Lactic Acid Bacteria Viability and Shelf Life Stability of Yoghurt
}

\author{
Ancuța M. ROTAR ${ }^{1}$, Dan Cristian VODNAR ${ }^{1 *}$, Florina BUNGHEZ ${ }^{1}$, Giorgiana Mihaela \\ CĂTUNESCU ${ }^{2}$, Carmen R. POP ${ }^{3}$, Mirela JIMBOREAN ${ }^{3}$, Cristina A. SEMENIUC ${ }^{3}$ \\ ${ }_{1,23}$ University of Agricultural Sciences and Veterinary Medicine, Cluj-Napoca, Department of Food Science ${ }^{1}$, Department of Technical and Soil Sciences, \\ Department of Food Engineering 33, 3-5 Mănăştur, Cluj-Napoca, 400372, Romania; dan.vodnar@usamvcluj.ro ('correspondingauthor)
}

\begin{abstract}
The probiotic properties and the viability of lactic acid bacteria of fermented dairy products can be improved by addition of bioactive compounds originating from natural sources (e.g. goji berries). This study aimed to evaluate how goji berries and honey affect the sensorial quality of yoghurt, the chemical properties, the viability of lactic acid bacteria (LAB) and the concurrent microflora development. Two types of yoghurts (yoghurt with goji berries and yoghurt with honey and goji berries) were developed. The addition of honey affected the entire yoghurt microflora including LAB, manifesting bactericidal effect. The addition of goji berries maintained the viability of LAB at probiotic levels $\left(10^{6}-10^{7} \log \mathrm{CFU} / \mathrm{ml}\right)$ during 21 days of storage; compared to classic yoghurt, LAB viability decreased during storage at $10^{3} \log \mathrm{CFU} / \mathrm{ml}$. Goji berries also improved sensory acceptance of consumers. The results obtained in this study collect information that enables the use of goji berries as enhancer of probiotic levels in yoghurt, while honey can provide bacteriostatic/bactericidal effect for contaminants.
\end{abstract}

Keywords: consumer acceptance, chemical parameters, plant extracts, probiotic

\section{Introduction}

Fermented dairy products are popular because of the health benefits provided by the ingestion of probiotics generated by the consumption of these products (Butel, 2014; Goktepe et al., 2006; Guarner and Schaafsma, 1998; Khalid, 2011; Sanders, 2003; Wang, 2009). Among all of the fermented dairy products yoghourt is the most consumed (Cruz et al., 2010; Cruz et al., 2013; de Oliveira, 2014; Saint-Eve et al., 2006), probably due to the positive perception on the market as being seen by the consumers as a functional dairy product containing living microorganisms like lactic acid bacteria (LAB), streptococci, bifidobacteria or their combinations, coming from the starter cultures, recognised as ingredients that promote human health (Davis, 2014; Goktepe et al., 2006; Kent et al., 2014; Khalid, 2011; Ouwehand et al., 2015; Rastall et al., 2002; Sanders et al., 2010). The market generated a need for fermented milk products that are fermented and processed in new conditions or enriched with bioactive compounds (Sun-Waterhouse et al., 2013; Zamfir et al., 2006).

Studies regarding the addition of different categories of bioactive molecules in yoghurt, including free-cell of probiotics, entrapped in different matrices and symbiotic forms (Brinques et al., 2011; Chavarri et al., 2010; Krasaekoopt et al., 2003; Lourens-Hattingh et al., 2001; Pinto et al., 2012; Stanton et al., 2001) and a wide range of plant extracts with various active properties as red berries (Breme et al., 2014; Cruz et al., 2010; Ścibisz et al., 2012; Sun-Waterhouse et al., 2013), grape and grape seed extracts (Chouchouli et al., 2013; Coda et al., 2012; Karaaslan et al., 2011; Tseng et al., 2013), pomegranate peel extract (El-Said et al., 2014), tea extracts (Jaziri et al., 2009; Ye et al., 2012) could be easily found. Researchers attempted to make the yoghurt a better environment for $\mathrm{LAB}$ and a source of bioactive compounds by addition of valuable molecules (Breme et al., 2014; do Espírito Santo et al., 2011).

The nutritional impacts of LAB and health benefits still continue to arise the interest of scientists who discover new potentials as food and valuable ingredients. Systems that can emphasize the great potential of probiotics are of interest. Saccharides are a good source food for these valuable bacteria, being utilized mostly as probiotics (Rastall et al., 2002; Teitelbaum et al., 2002; Wang, 2009). The benefits brought by carotenoid consumption include reduction of cancer risk or cardiovascular diseases (Pintea $e t$ al., 2005; Pintea et al., 2011; Socaciu et al., 2000), improving vision (Pintea et al., 2011) and a healthy tan looking effect.

Polyphenols possess strong antioxidant activities being free radical scavengers, electron donors and strong metal chelators (Andjelković et al., 2006), helping in the prevention of lipid peroxidation (Vodnar et al., 2014). Several reports have shown 
Table 1. Experimental design-treatments and responses

\begin{tabular}{|c|c|c|c|}
\hline Treatments & Responses & Treatments & Responses \\
\hline Sensory evaluation & & Physicochemical and microbiological analysis & \\
\hline YC(classicyoghurt) & $\mathrm{X}$ & $\mathrm{YC}_{\mathrm{i}}$ (classic yoghurt-initial) & $\mathrm{xx}$ \\
\hline $\mathrm{YG}_{3}$ (yoghurt with 3\% gojiberries) & $\mathrm{X}$ & $\mathrm{YG}_{\mathrm{7}_{\mathrm{i}}}$ (yoghurt with $7 \%$ goji berries-initial) & $\mathrm{xx}$ \\
\hline YG5 (yoghurt with $5 \%$ gojiberries) & $\mathrm{X}$ & $\mathrm{YHG}_{\pi_{1}}$ (yoghurt with honey and $7 \%$ gojiberries-initial) & $\mathrm{xx}$ \\
\hline $\mathrm{YG}_{7}$ (yoghurt with $7 \%$ gojiberries) & $\mathrm{X}$ & $\mathrm{YC}_{\mathrm{m}}$ (classicyoghurt-middle of storage-14 $14^{\text {th }}$ day of storage) & $\mathrm{xx}$ \\
\hline $\mathrm{YHG}_{3}$ (yoghurt with honey and $3 \%$ goji berries) & $\mathrm{X}$ & $\mathrm{YG}_{7 \mathrm{~m}}$ (yoghurt with $7 \%$ goji berries-middle of storage-14 $4^{\text {th }}$ day of storage) & $\mathrm{xx}$ \\
\hline $\mathrm{YHG}_{5}$ (yoghurt with honey and $5 \%$ goji berries) & $\mathrm{X}$ & $\mathrm{YHG}_{7 \mathrm{~m}}$ (yoghurt with honey and $7 \%$ goji berries-middle of storage- $14^{\text {th }}$ day of storage) & $\mathrm{xx}$ \\
\hline \multirow[t]{3}{*}{ YHG (yoghurt with honey and $7 \%$ goji berries) } & $\mathrm{X}$ & $\mathrm{YC}_{\mathrm{f}}$ (classic yoghurt-final of storage-2 $1^{ \pm}$day of storage) & $\mathrm{xx}$ \\
\hline & & $\mathrm{YG}_{7 \mathrm{f}}$ (yoghurt with $7 \%$ goji berries-final of storage-21 ${ }^{\star}$ day of storage) & $\mathrm{xx}$ \\
\hline & & $\mathrm{YG}_{\mathrm{7f}}$ (yoghurt with $7 \%$ goji berries-final of storage- $21^{\star}$ day of storage) & $\mathrm{xx}$ \\
\hline
\end{tabular}

that polyphenols prevent the proliferation of degenerative diseases, clearly improving the condition of oxidative stress biomarkers (Bunea et al., 2013; Chedea et al.,2010).

Lycium barbarum (goji berries or wolfberries, Solanaceae family) represent a rich source of chemical, having health promoting properties: ocular neuroprotecti (Srinivasan, 2014), hepato-protective (Liu et al., 2015), antitumoral (How et al., 2014; Martínez et al, 2014), antioxidative and immunomodulatory effects (Xiao et al., 2012). These properties are related to the saccharides, caroteinoids and some phenolics in the soluble fraction (Bondia-Pons et al., 2014; Inbaraj et al., 2010; Wang et al., 2010; Xiao et al,, 2012; Yang et al., 2013). Honey contains phenolic acids and their derivates, flavonoids and hydrogen peroxide (Brudzynski, 2006; Brudzynski et al., 2011); it has high osmolarity, low pH and water activity (Voidarou et al., 2011). Thus, honey could provide good bacteriostatic or bactericide effect. Research showed that the redox potential can be reduced by supplementing yoghurt with bioactive compounds from natural sources (Perna et al., 2014; Zalibera et al., 2008). Moreover, the viability of LAB ( $L$. bulgaricus and $S$. thermophilus) could be increased by reducing the redox potential with addition of bioactive compounds from natural sources (Zalibera et al., 2008).

In this study it was investigated how goji berries and honey affected the sensorial quality, the chemical properties, the viability of lactic acid bacteria and concurrent microflora in yoghurt. Two types of yoghurt were obtained with different concentrations of goji berries and honey.

\section{Materials and methods}

\section{Yoghurtpreparation}

Whole milk was provided by UASVM farm together with an analysis bulletin (fat content - 3.87\%; protein content $3.40 \%$; crioscopic point: $-0.60^{\circ} \mathrm{C}$; non-fat dry matter $-9.10 \%$; density $-1.0295 \mathrm{~g} / \mathrm{cm}^{3}$ ). Classic yoghurt was prepared starting from whole milk (3.5\% fat), pre-heated (homogenized) at 50 $65^{\circ} \mathrm{C}\left(150-200 \mathrm{~atm}\right.$ ), pasteurized at $85-90^{\circ} \mathrm{C}$ (maintained for 20-30 $\mathrm{min}$ ) and cooled at $45-48^{\circ} \mathrm{C}$. Starter mezophylic culture Lyofast Y450B (Sacco, Cadorago, Italy) containing Streptococcus thermophilus and Lactobacillus delbrueckii subsp. bulgaricus (ratio 1:1) was added (5 units at $250 \mathrm{~L}$ milk which correspond to $0.5 \times 10^{12} \mathrm{CFU} / \mathrm{ml}$ ) to start fermentation. The yoghurt was stored at $43-45^{\circ} \mathrm{C}$ for 3 hours, pre-cooled at $18-20$ ${ }^{\circ} \mathrm{C}$, cooled at $2-8{ }^{\circ} \mathrm{C}$ and stored at this temperature for further analysis (Jimborean and Țibulcă, 2013).

The classic yoghurt was supplemented with 3\%, 5\% and $7 \%(\mathrm{w} / \mathrm{w})$ goji berries, after the inoculation with starter culture.
The same technology was used for yoghurt with honey and goji berries; polyfloral honey 3\% (w/w) was added before fermentation and goji berries in amount of 3\%, 5\%, and 7\% $(\mathrm{w} / \mathrm{w})$ after fermentation. Goji berries and honey were purchased from a local market.

\section{Total phenolic content of goji berries}

Goji berries $(2.5 \mathrm{~g})$ were cut in small pieces, homogenized using a rotary magnetic stirrer with $10 \mathrm{~mL}$ distilled water, centrifuged at $3,000 \times g$ for $10 \mathrm{~min}$. The supernatant was analyzed spectrophotometrically using Folin-Ciocâlteu method. Aliquots of $2.375 \mathrm{~mL}$ distilled water were mixed with $0.025 \mathrm{~mL}$ extract, $0.150 \mathrm{~mL}$ Folin-Ciocâlteu reagent and 0.450 $\mathrm{mL} \mathrm{Na}_{2} \mathrm{CO}_{3}(7.5 \%)$. Absorbance was read at $750 \mathrm{~nm}$ (Biotek multiplate reader) after keeping the samples for 2 hours in the dark. Results were expressed as mg of gallic acid equivalents (GAE) $100 \mathrm{~g}^{-1}$ goji berries.

\section{Experimental design}

Two types of yoghurt were obtained in this study: yoghurt with goji berries (YG) and yoghurt with honey and goji berries (YHG). Classic yoghurt (YC) was the control sample. Goji berries were added in proportions of 3\%,5\% and $7 \%(\mathrm{w} / \mathrm{v})$ in classic yoghurt $\left(\mathrm{YG}_{3}, \mathrm{YG}_{5}\right.$ and $\left.\mathrm{YG}_{7}\right)$ and in yoghurt with honey $\left(\mathrm{YHG}_{3}, \mathrm{YHG}_{5}\right.$ and $\left.\mathrm{YG}_{7}\right)$. Samples codification and experimental design are shown in Table 1.

Yoghurt with $3 \%, 5 \%$ and $7 \%$ goji berries $\left(\mathrm{YG}_{3}, \mathrm{YG}_{5}, \mathrm{YG}_{7}\right)$ and yoghurt with honey $(3 \%)$ and goji berries $\left(\mathrm{YHG}_{3}, \mathrm{YHG}_{5}\right.$, $\mathrm{YHG}_{7}$ ), were sensory evaluated. Further studies (chemical and microbiological analysis) were conducted on classic yoghurt, yoghurt with 7\% goji berries, and yoghurt with honey and 7\% goji berries during a shelf life of 21 days at $4{ }^{\circ} \mathrm{C}$. The samples were analyzed initial $(\mathrm{i})$, in the $14^{\text {th }}$ day of storage $(\mathrm{m})$ and in the $21^{\text {st }}$ day of storage (f). Fat, proteins, lactic acid, lactose, glucose, fructose, sucrose, total sugars, total solids and solids non-fat were tested. Salmonella spp., Enterobacter spp. and Escherichia coli were determined as microbial contaminants and Streptococcus thermophilus and Lactobacillus bulgaricus as lactic acid bacteria.

\section{Sensory evaluation of yoghurt}

A 9-point hedonic test was used to determine consumer's preference of yoghurt. Yoghurt with 3\%, 5\% and 7\% goji berries $\left(\mathrm{YG}_{3}, \mathrm{YG}_{5}, \mathrm{YG}_{7}\right)$ and yoghurt with honey $(3 \%)$ and goji berries $\left(\mathrm{YHG}_{3}, \mathrm{YHG}_{5}, \mathrm{YHG}_{7}\right)$ were sensory evaluated. A panel of 30 trained assessors (male and female) participated to this study. The response categories ranged from 1-extreme dislike, to 9-extreme like. 
198

Chemical analysis of yoghurt

$10 \mathrm{~mL}$ of yoghurt were homogenized using a stomacher (Bagmixer-100MiniMix, Interscience, Arpents, France) before the chemical analysis, as sample preparation.

The chemical content (fat, proteins, lactic acid, lactose, glucose, fructose, sucrose, total sugars, total solids and solids non-fat) of the yoghurt was determined using the MilkoScan FT2 analyser (Foss, Hillerød, Denmark).

The method was based on a mathematic procedure that allowed splitting the interferogram in sinus functions, each one representing a wavelength. The interferogram was then introduced in a spectrophotometer and converted in a larger spectral image of the sample. The results were expressed as percentage.

\section{Determination of lactic acid bacteria in yoghurt}

Lactic acid bacteria in yoghurt with $7 \%$ goji berries and in yoghurt with honey and goji berries was initially determined, after the $14^{\text {th }}$ day of storage and after the $21^{\text {st }}$ day of storage. Yoghurt samples were ten-fold diluted, placed on MRS broth/M17 broth, (Oxoid, Basingstoke, UK) and incubated in anaerobic conditions for $72 \mathrm{~h}$ at $37^{\circ} \mathrm{C}$ (L. bulgaricus) and for $48 \mathrm{~h}$ at $37^{\circ} \mathrm{C}$ (S. thermophilus). Plates containing 30 to 300 CFU were counted. The confirmation was made by specific test (Gram affinity, colony aspect and catalase + ).

Determination of microbial pathogens in yoghurt

Three strains of Gram negative bacteria (Salmonella spp., Enterobacter spp. and Escherichia coli) and one Gram positive strain (Staphylococcus spp.) were tested for yoghurts and aqueous extract of goji ( 5 g goji berries in $45 \mathrm{~mL}$ physiological serum). Honey was microbiological evaluated according to the same methodology as goji berries.

\section{Identification of Salmonella spp.}

The presence of Salmonella was determined according to SR ISO 6579/1997 method. For the pre-enrichment stage, the sample was suspended in Buffered Peptone Water (Laboratorios Conda, Madrid, Spain). For the enrichment stage, $1.0 \mathrm{~mL}$ of sample was inoculated on RVS broth (Merck, Darmstadt, Germany) and incubated at $42^{\circ} \mathrm{C}$ for $24 \mathrm{~h}$. The isolation was made by inoculating the bacterial suspension obtained in the enrichment phase on XLD Agar (Oxoid, Basingstoke, UK) and Brilliant Green Agar (modified CM0329, Oxoid, Basingstoke, UK). The incubation was made at $35-37^{\circ} \mathrm{C}$ for $20-24 \mathrm{~h}$ (another $24 \mathrm{~h}$ if necessary). The confirmation was made on characteristic colonies using selective growth mediums. The results were expressed as colony forming units per gram (CFU $25 \mathrm{ml}^{-1}$ ).

\section{Identification of Enterobacterspp.}

The presence of Enterobacter was made according to SRISO 21528-2/2007 method. Briefly, $1.0 \mathrm{~mL}$ of the diluted sample was transferred to a sterile Petri dish. Aliquots of $15 \mathrm{~mL}$ of Violet Red Bile Glucose Agar (Lab M Ltd., Lancashire, UK) were poured over the sample and maintained at $45 \pm 1{ }^{\circ} \mathrm{C}$. In order to ensure semi-anaerobic conditions, another $15 \mathrm{~mL}$ of VRBGA agar were poured into the Petri dish. Incubation was made at $35^{\circ} \mathrm{C}$ for $24 \mathrm{~h}$. The results were expressed as Log $\mathrm{CFU} / \mathrm{ml}$.

\section{Identification of Escherichia coli}

The presence of $E$. coli was determined according to SR ISO 7251/1996. $1.0 \mathrm{~mL}$ of the diluted sample was uniformly distributed into a sterile Petri dish and then TBX Agar (Oxoid, Basingstoke, UK) was poured and mixed. The incubation was made at $35^{\circ} \mathrm{C}$ for $24 \mathrm{~h}$. The results were expressed as Log $\mathrm{CFU} / \mathrm{ml}$.

\section{Identification of Staphylococcus aureus}

SR EN ISO 6888-2/A-1/2005 standard method was used. Briefly, $1.0 \mathrm{~mL}$ of the diluted sample was transferred to a sterile Petri dish covered with Baird-Parker agar (Oxoid, Basingstoke, UK) supplemented with Egg Yolk Tellurite Supplement (SR 00540, Oxoid, Basingstoke, UK) and spread using a Drigalsky spatula. The results were expressed as $\mathrm{Log} \mathrm{CFU} / \mathrm{ml}$.

\section{Statistical analysis}

Statistical analysis of data was performed by Minitab Statistical software version 16.1.0 (LEAD Technologies, Inc.). The analysis of variance was assessed by two-way ANOVA and significant differences among the means of samples were analyzed by Tukey's test with a $95 \%$ confidence level.

\section{Results and discussions}

\section{Totalphenolic content of goji berries}

The total phenolic content (TPC) of goji berries water extract

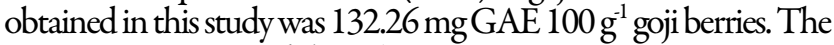
study of Hunaefi et al. (2012) reports that phenolic compounds are secondary metabolites that can interfere with the LAB fermentation process through their antioxidant properties.

Donno et al. (2014) evaluated TPC of various cultivars of fresh goji berries and determined values ranging from 255.87 to 281.91 mg GAE $\mathrm{g}^{-1}$ fresh weight (FW), while Medina et al. (2011) obtained higher values in dry goji berries extracted in ethanol (895 mg GAE g-1 DW). Differences can be attributed to genotype, cultivars (Donno et al., 2014), extraction type, mainly solvent polarity (Medina et al., 2011) processing and method sensibility.

\section{Sensory evaluation by Hedonic test}

The sensory evaluation showed that the consumers preferred yoghurt with $7 \%$ goji berries (8.21 points on hedonic scale). Yoghurt with goji berries and honey was less accepted by consumers. Yoghurt with honey and $7 \%$ goji berries scored 7.4 points, while yoghurt with honey and 3\% goji berries scored the lowest 6.9 points on hedonic scale (Fig. 1).

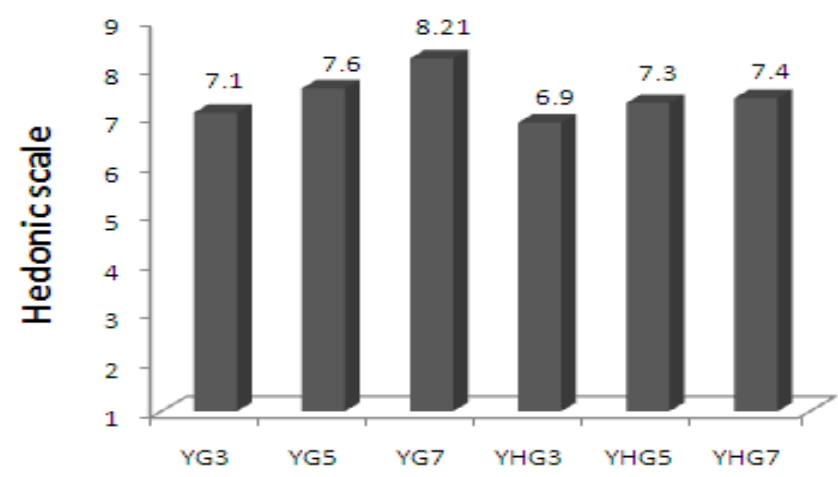

Fig. 1. Graphical representation of the sensory evaluation of yoghurt, according to the hedonic scale 
Table 2. Results of the physicochemical evaluation of tested yoghurts

\begin{tabular}{|c|c|c|c|c|c|c|c|c|c|c|}
\hline Sample & Fat (\%) & $\begin{array}{c}\text { Proteins } \\
(\%)\end{array}$ & $\begin{array}{l}\text { Lactic acid } \\
(\%)\end{array}$ & $\begin{array}{l}\text { Lactose } \\
(\%)\end{array}$ & $\begin{array}{c}\text { Sucrose } \\
(\%)\end{array}$ & $\begin{array}{c}\text { Glucose } \\
(\%)\end{array}$ & $\begin{array}{c}\text { Fructose } \\
(\%)\end{array}$ & $\begin{array}{l}\text { Total sugars } \\
\text { (\%) }\end{array}$ & $\begin{array}{c}\text { Total solids } \\
(\%)\end{array}$ & $\begin{array}{c}\text { Solids non-fat } \\
\text { (\%) }\end{array}$ \\
\hline $\mathrm{YC}_{\mathrm{i}}$ & $4.51 \pm 0^{\mathrm{d}}$ & $3.66 \pm 0^{f}$ & $0.61 \pm 0.01^{\mathrm{cd}}$ & $4.77 \pm 0^{a}$ & $0.04 \pm 0.01^{\mathrm{c}}$ & $0.00 \pm 0^{f}$ & $0.20 \pm 0^{f}$ & $4.14 \pm 0^{g}$ & $13.84 \pm 0^{\mathrm{i}}$ & $9.24 \pm 0^{h}$ \\
\hline $\mathrm{YG}_{7 \mathrm{i}}$ & $4.50 \pm 0^{\mathrm{d}}$ & $3.73 \pm 0^{c}$ & $0.61 \pm 0^{\text {bcd }}$ & $4.72 \pm 0.01^{\mathrm{b}}$ & $0.02 \pm 0^{c}$ & $0.03 \pm 0^{c}$ & $0.24 \pm 0^{c}$ & $4.17 \pm 0^{f}$ & $13.96 \pm 0^{\mathrm{g}}$ & $9.31 \pm 0^{\mathrm{g}}$ \\
\hline $\mathrm{YHG}_{\mathrm{7i}}$ & $4.52 \pm 0.01^{\mathrm{d}}$ & $3.67 \pm 0.01^{f}$ & $0.60 \pm 0.01^{\mathrm{d}}$ & $4.74 \pm 0^{b}$ & $0.02 \pm 0^{c}$ & $0.00 \pm 0^{f}$ & $0.21 \pm 0^{f}$ & $4.15 \pm 0.01^{\mathrm{fg}_{\mathrm{g}}}$ & $13.90 \pm 0^{h}$ & $9.25 \pm 0^{\mathrm{h}}$ \\
\hline $\mathrm{YC}_{\mathrm{m}}$ & $4.32 \pm 0^{c}$ & $4.18 \pm 0.01^{b}$ & $0.63 \pm 0^{\mathrm{bc}}$ & $3.82 \pm 0^{d}$ & $0.35 \pm 0.01^{\mathrm{ab}}$ & $1.96 \pm 0^{c}$ & $3.45 \pm 0.01^{2}$ & $8.76 \pm 0.01^{2}$ & $20.91 \pm 0.01^{\mathrm{a}}$ & $16.40 \pm 0.01^{c}$ \\
\hline $\mathrm{YG}_{7 \mathrm{~m}}$ & $4.20 \pm 0^{f}$ & $4.22 \pm 0^{a}$ & $0.63 \pm 0.01^{\mathrm{bc}}$ & $3.65 \pm 0.01^{f}$ & $0.27 \pm 0^{\mathrm{d}}$ & $2.06 \pm 0^{a}$ & $3.45 \pm 0.01^{a}$ & $8.72 \pm 0.01^{b}$ & $20.85 \pm 0.01^{c}$ & $16.56 \pm 0.01^{2}$ \\
\hline $\mathrm{YHG}_{7 \mathrm{~m}}$ & $4.22 \pm 0.01^{f}$ & $4.23 \pm 0.01^{a}$ & $0.63 \pm 0^{\mathrm{b}}$ & $3.76 \pm 0.01^{\mathrm{c}}$ & $0.35 \pm 0^{2}$ & $2.01 \pm 0^{\mathrm{b}}$ & $3.40 \pm 0.01^{b}$ & $8.74 \pm 0.01^{\mathrm{ab}}$ & $20.88 \pm 0.01^{b}$ & $16.49 \pm 0.01^{b}$ \\
\hline $\mathrm{YC}_{\mathrm{f}}$ & $5.51 \pm 0.01^{a}$ & $4.14 \pm 0.01^{c}$ & $1.17 \pm 0.0^{2}$ & $3.87 \pm 0.01^{c}$ & $0.30 \pm 0^{c}$ & $1.32 \pm 0^{d}$ & $2.35 \pm 0^{c}$ & $7.13 \pm 0.01^{\mathrm{c}}$ & $20.16 \pm 0.01^{d}$ & $14.46 \pm 0.01^{f}$ \\
\hline $\mathrm{YG}_{7 \mathrm{f}}$ & $5.42 \pm 0.01^{c}$ & $4.08 \pm 0.01^{d}$ & $1.17 \pm 0.0^{2}$ & $3.82 \pm 0.01^{\mathrm{d}}$ & $0.27 \pm 0^{d}$ & $1.32 \pm 0^{d}$ & $2.31 \pm 0^{\mathrm{d}}$ & $6.99 \pm 0^{c}$ & $20.06 \pm 0.01^{f}$ & $14.56 \pm 0.01^{\mathrm{d}}$ \\
\hline $\mathrm{YHG}_{7 f}$ & $5.46 \pm 0.01^{\mathrm{b}}$ & $4.13 \pm 0^{c}$ & $1.17 \pm 0.0^{2}$ & $3.87 \pm 0^{c}$ & $0.33 \pm 0^{\mathrm{b}}$ & $1.31 \pm 0^{\mathrm{d}}$ & $2.31 \pm 0^{d}$ & $7.04 \pm 0.01^{\mathrm{d}}$ & $20.13 \pm 0.01^{\mathrm{c}}$ & $14.52 \pm 0.01^{\mathrm{c}}$ \\
\hline
\end{tabular}

Table 3. Effects of yoghurt type, storage time and their first-degree interaction on fat $(\%)$, proteins (\%), lactic acid (\%), lactose (\%), sucrose (\%), glucose (\%), fructose (\%), total sugars (\%), total solids (\%), solids non-fat (\%) and their percentage contribution

\begin{tabular}{|c|c|c|c|c|c|c|c|c|c|c|}
\hline Factor & Fat $(\%)$ & Proteins(\%) & $\begin{array}{l}\text { Lactic acid } \\
(\%)\end{array}$ & Lactose (\%) & Sucrose (\%) & Glucose (\%) & $\begin{array}{c}\text { Fructose } \\
(\%)\end{array}$ & $\begin{array}{c}\text { Total sugars } \\
(\%)\end{array}$ & $\begin{array}{c}\text { Total solids } \\
\text { (\%) }\end{array}$ & $\begin{array}{l}\text { Solidsnon-fat } \\
\text { (\%) }\end{array}$ \\
\hline \multicolumn{11}{|l|}{ Yoghurt type(YT) } \\
\hline YC & $4.8^{\mathrm{a}}$ & $4.0^{b}$ & $0.8^{a}$ & $4.2^{\mathrm{a}}$ & $0.2^{\mathrm{a}}$ & $1.1^{\mathrm{c}}$ & $2.0^{2}$ & $6.7^{\mathrm{a}}$ & $18.3^{\mathrm{a}}$ & $13.4^{c}$ \\
\hline YG & $4.7^{c}$ & $4.0^{\mathrm{a}}$ & $0.8^{\mathrm{a}}$ & $4.1^{\mathrm{c}}$ & $0.2^{\mathrm{b}}$ & $1.1^{\mathrm{a}}$ & $2.0^{\mathrm{a}}$ & $6.6^{c}$ & $18.3^{b}$ & $13.5^{\mathrm{a}}$ \\
\hline YHG & $4.7^{b}$ & $4.0^{\mathrm{a}}$ & $0.8^{\mathrm{a}}$ & $4.1^{\mathrm{b}}$ & $0.2^{\mathrm{a}}$ & $1.1^{\mathrm{b}}$ & $2.0^{\mathrm{b}}$ & $6.6^{b}$ & $183^{\mathrm{a}}$ & $13.4^{\mathrm{b}}$ \\
\hline SD/Contribution (\%) & ${ }^{* * *} / 0.34$ & ${ }^{* *} / 0.12$ & n.s. $/ 0$ & ***/0.72 & $* * * / 2.32$ & ***/0.05 & ***/0.01 & ***/0.01 & ${ }^{* *} / 0.001$ & ***/0.02 \\
\hline \multicolumn{11}{|l|}{ Storage time $(\mathrm{ST})$} \\
\hline Initial & $4.5^{\mathrm{b}}$ & $3.7^{\mathrm{c}}$ & $0.6^{c}$ & $4.7^{\mathrm{a}}$ & $0.0^{c}$ & $0.0^{c}$ & $0.2^{c}$ & $4.2^{c}$ & $13.9^{c}$ & $9.3^{c}$ \\
\hline Middle stage of storage & $4.2^{c}$ & $4.2^{\mathrm{a}}$ & $0.6^{\mathrm{b}}$ & $3.7^{\mathrm{c}}$ & $0.3^{\mathrm{a}}$ & $2.0^{2}$ & $3.4^{\mathrm{a}}$ & $8.7^{\mathrm{a}}$ & $20.1^{\mathrm{b}}$ & $16.5^{\mathrm{a}}$ \\
\hline Final stage of storage & $5.5^{\mathrm{a}}$ & $4.1^{\mathrm{b}}$ & $1.2^{\mathrm{a}}$ & $3.8^{\mathrm{b}}$ & $0.3^{\mathrm{b}}$ & $1.3^{\mathrm{b}}$ & $2.3^{\mathrm{b}}$ & $7.0^{\mathrm{b}}$ & $20.9^{a}$ & $14.5^{\mathrm{b}}$ \\
\hline SD/Contribution (\%) & ${ }^{* * *} / 99.48$ & $* * * / 98.59$ & $* * * / 99.96$ & ***/98.98 & $* * * / 96.33$ & ***/99.91 & $* * * / 99.98$ & $* * * / 99.97$ & ${ }^{* * *} / 99.98$ & ***/99.98 \\
\hline \multicolumn{11}{|l|}{ YTxST } \\
\hline SD/Contribution (\%) & $* / 0.17$ & $* * * / 1.26$ & n.s./0.01 & ***/0.29 & $* * * / 1.30$ & ***/0.04 & ${ }^{* * *} / 0.01$ & ***/0.02 & ***/0.02 & ${ }^{* * *} / 0.003$ \\
\hline
\end{tabular}

${ }^{17}$ Different letters indicates statistically significant differences at $p<0.05$ (Tukey's test)

2) Significant differences (SD) are denoted by asterisks: ${ }^{*} p<0.05 ;{ }^{* *} p<0.01 ;{ }^{* * *} p<0.001 ;$ n.s. $p \geq 0.05$, non-significant

${ }^{3)}$ YC (classic yoghurt); YG (yoghurt with 7\% goji berries); YHG (yoghurt with honey and $7 \%$ goji berries)

In general, fruity yoghurts are popular among consumers (Kailasapathy et al., 2008). Senaka Ranadheera et al. (2012) also reported a higher preference of yoghurts supplemented with fruits. No previous report evaluated the sensory attributes of fruity yoghurt supplemented with honey. In this study the addition of honey influenced negatively the consumer's perception.

\section{Chemical evaluation of yoghurts}

Chemical analysis evaluated the effects of fortification and shelf life stability on yoghurt (Table 2). The effects of yoghurt type, storage time and crossed treatment interaction on chemical properties were analyzed by two-way ANOVA and Tukey's test. Significant differences were observed in chemical attributes dependent on yoghurt type, storage time and cross treatment interaction (Table 3).

Sucrose had the highest percentage of contribution of yoghurt type $(2.32 \%, p<0.001)$; sucrose accumulated in yoghurts towards the end of shelf life. The quantity of sucrose increased during storage for all types of yoghurt. Sucrose from honey was solubilized in yoghurt and lead to high values of sugars (Tewari et al., 2004) (Table 2). This increase might occur due to efflux of intracellular carbohydrates associated with the disaccharide metabolism and can be observed in case of LAB. The lowest percentage contribution on yoghurt type was determined for total solids followed by fructose, total sugars and solid non-fat.

An increasing tendency for glucose and fructose was observed until the $14^{\text {th }}$ day of storage because saccharides from honey and goji berries were solubilized. This can be also explained by the fact that lactose was decomposed by lactic acid bacteria. Moreover, LAB have the ability to decrease the carbohydrates content by fermentation process.

Storage influenced the content of lactic acid with a contribution of $99.96 \%$. The content of lactose decreased and lactic acid increased during storage (lactose is decomposed into lactic acid). Lactic acid showed insignificant differences in relation to yoghurt type, but a direct contribution to storage time and an increasing tendency was found towards the end of shelf life (Table 3).

Storage time influenced significantly the content of total solids, solids non-fat, fructose (99.98\%), total sugars (99.97\%) and glucose (99.91\%). Lactic acid bacteria consumed glucose and fructose resulting in low quantities at the end of the storage. In case of yoghurt with $7 \%$ goji berries, glucose decreased from $2.06 \%$ to $1.32 \%$, while fructose decreased from $3.45 \%$ to $2.35 \%$. In yoghurt honey and with $7 \%$ goji berries, glucose decreased from $2.01 \%$ to $1.31 \%$ and fructose from $3.40 \%$ to $2.31 \%$. Classic yoghurt showed a similar decreasing tendency for glucose and fructose, from $1.96 \%$ to $1.32 \%$ and from $3.45 \%$ to $2.35 \%$, respectively.

Solid non-fat, total solids and total sugars increased until the $14^{\text {th }}$ day of storage and decreased in the $21^{\text {to }}$ day of storage; the type of yoghurt had little influence on these parameters. The total sugar content for yoghurt with 7\% goji berries ranged from $4.17 \%$ (initial) to $8.72 \%$ in the $14^{\text {th }}$ day of storage and decreased at $6.99 \%$ in the $21^{\text {t }}$ day of storage. The same tendency was observed in case of total solids and solid non-fat (Table 2). The higher amount of total solids (including fat and protein content) was found in yoghurts in the $21^{\text {st }}$ day of storage. 
Table 4. Microbiological evaluation of yoghurt, goji berries and honey

\begin{tabular}{|c|c|c|c|c|c|c|c|c|c|c|c|}
\hline \multirow{2}{*}{ Contaminant } & \multicolumn{11}{|c|}{ Samples } \\
\hline & $\mathrm{YC}_{\mathrm{i}}$ & $\mathrm{YC}_{\mathrm{m}}$ & $\mathrm{YC}_{\mathrm{f}}$ & $\mathrm{YG}_{7 \mathrm{i}}$ & $\mathrm{YG}_{\mathrm{7m}_{\mathrm{m}}}$ & $\mathrm{YG}_{7 \mathrm{ff}}$ & $\mathrm{YHG}_{7 \mathrm{i}}$ & $\mathrm{YHG}_{7_{\mathrm{m}}}$ & $\mathrm{YHG}_{7 \mathrm{f}}$ & Goji berries & Honey \\
\hline $\begin{array}{l}\text { Salmonella } \\
\log \mathrm{CFU} / \\
25 \mathrm{ml}\end{array}$ & ND & ND & ND & ND & ND & ND & ND & ND & ND & ND & ND \\
\hline $\begin{array}{l}\text { E. coli log } \\
\mathrm{CFU} / \mathrm{ml}\end{array}$ & ND & ND & ND & ND & $0.35 \times 10^{2} \pm 1.77$ & $0.55 \times 10^{2} \pm 1.77$ & ND & ND & $0.72 \times 10^{2} \pm 2.0$ & $0.35 \times 10^{3} \pm 1.77$ & ND \\
\hline $\begin{array}{l}\text { Enterobacter } \\
\log \mathrm{CFU} / \mathrm{ml}\end{array}$ & ND & ND & ND & ND & $0.6 \times 10^{2} \pm 0.44$ & $0.35 \times 10^{2} \pm 1.77$ & ND & ND & $0.4 \times 10^{2} \pm 1.11$ & $1.6 \times 10^{3} \pm 0.44$ & ND \\
\hline $\begin{array}{l}\text { S. aureus } \\
\log \mathrm{CFU} / \mathrm{ml}\end{array}$ & ND & ND & ND & ND & $\mathrm{ND}$ & ND & ND & ND & ND & ND & ND \\
\hline Lactic acid Bact & & & & & & & & & & & \\
\hline $\begin{array}{l}\text { Str. } \\
\text { thermophilus } \\
\log \mathrm{CFU} / \mathrm{ml}\end{array}$ & $1.38 \times 10^{7}$ & $1.46 \times 10^{6}$ & $1.50 \times 10^{3}$ & $2.14 \times 10^{8}$ & $1.99 \times 10^{7}$ & $1.76 \times 10^{7}$ & $1.7 \times 10^{7}$ & $1.63 \times 10^{6}$ & $2.06 \times 10^{5}$ & NA & NA \\
\hline $\begin{array}{l}\text { L. bulgaricus } \\
\log \mathrm{CFU} / \mathrm{ml}\end{array}$ & $1.59 \times 10^{7}$ & $1.51 \times 10^{6}$ & $1.33 \times 10^{3}$ & $2.17 \times 10^{8}$ & $2.71 \times 10^{7}$ & $1.67 \times 10^{7}$ & $1.30 \times 10^{8}$ & $1.33 \times 10^{6}$ & $1.71 \times 10^{5}$ & NA & NA \\
\hline
\end{tabular}

Crossed treatment interaction revealed significant differences in the content of sucrose $(1.30 \%$ contribution, $p<0.001)$ and proteins $(1.26 \%$ contribution, $p<0.001)$, while the smallest percentage of contribution was determined in case of solids non-fat $(0.003 \%, p<0.001)$ and fructose $(0.02 \%, p<0.001)$.

\section{Lactic acid bacteria}

Lactic acid bacteria concentration remained at probiotic value level $\left(10^{6}-10^{7} \mathrm{Log} \mathrm{CFU} / \mathrm{ml}\right)$ (Shiby et al., 2013) in yoghurt with $7 \%$ goji berries addition during storage and decreased in yoghurt with honey and $7 \%$ goji berries (Table 4 ).

S. termophillus concentration decreased during storage in all yoghurt types because of its sensitivity to lactic acid. A slight maintenance of $S$. termophillus concentration was observed during the first week of storage. One of the most important properties of lactic acid bacteria is their ability to decrease the carbohydrates content by fermentation. Until the $14^{\text {th }}$ day of storage, lactic acid bacteria had sufficient carbohydrates to synthesize lactic acid (Tables 2 and 4); in the $21^{\text {st }}$ day of storage, lactic acid bacteria viability decreased and once with it the ability to metabolize carbohydrates.

The growth of probiotics/prebiotics and yoghurt starter culture in the presence of fruit juices is strain specific (Vinderola $e t$ al., 2002). The data presenting the growth and viability of lactobacilli in this particular medium is scarce (Kailasapathy et al., 2008; Vinderola et al., 2002).

The production of lactic acid by Lactobacillus is influenced by the medium $\mathrm{pH}$. Chookietwattana (2014) reported that at an initial $\mathrm{pH}$ of 6.5 the lactic acid production was high, whereas at a $\mathrm{pH}$ of $5.0 / 5.5$ the production of lactic acid was prohibited.

The same evolution in lactic acid bacteria concentration was observed by Michael et al. (2010), while Rotar et al. (2007) reported a significant decrease of the viable germs to $10^{3} \log$ $\mathrm{CFU} / \mathrm{ml}$ at the end of the storage period in classic yoghurt.

\section{Microbiological evaluation of yoghurt}

Salmonella spp. and Staphylococcus spp. were absent in all types of yoghurt (Table 3). Contamination with E. coli was determined in goji berries yogurts. In the $14^{\text {th }}$ day of storage the yoghurt with goji berries resulted positive for contamination. The presence of $E$. coli was noted in case of yoghurt with honey and goji berries in the $21^{\text {st }}$ day of storage.
The presence of Enterobacter was detected in the $21^{\mathrm{t}}$ day of storage for yoghurt with honey and goji berries. The initial levels of Enterobacter spp. in goji berries was $1.6 \times 10^{3} \log \mathrm{CFU} / \mathrm{ml}$; these values were reduced in the $21^{\text {tt }}$ day of storage at $0.4 \times 10^{2} \log$ $\mathrm{CFU} / \mathrm{ml}$, proving bacteriostatic effect by adding honey. Salmonella spp. and Staphylococcus spp. were absent in all types of yoghurt (Table 3). Contamination with E. coli was determined in goji berries. In the $14^{\text {th }}$ day of storage the yoghurt with goji berries resulted positive for contamination. The presence of $E$. coli was noted in case of yoghurt with honey and goii berries in the $21^{\text {st }}$ day of storage. Literature reports the bactericide/bacteriostatic effect of honey (Brudzynski et al., 2012; Brudzynski et al, 2011; Voidarou et al.,2011).

\section{Conclusions}

The addition of goji berries (7\%) improved the sensory quality of classic yoghurt and increased the consumer's acceptance. Quality parameters (chemical parameters) were maintained during storage. Goji berries improved the lactic acid bacteria evolution and maintained the prebiotic value of yoghurt during storage. Concurrent microflora (contaminants) appeared when goji berries were added. The results obtained in this study collect information that enables the use of goji berries as enhancer of probiotic levels in yoghurt.

\section{Acknowledgements}

This study has been financed by the Romanian Ministry of Education and Research, PN-II-IN-CI -2013-1-0089 project (nr. 207/CI/2013) and USAMV-CN/1215/15/06.02.2012 academic grant and under the frame of European Social Fund, Human Resources Development Operational Program 2007-2013, projectno. POSDRU/159/1.5/S/132765.

\section{References}

Andjelković M, Van Camp J, De Meulenaer B, Depaemelaere G, Socaciu C, Verloo M, Verhe R (2006). Iron-chelation properties of phenolic acids bearing catechol and galloyl groups. Food Chemistry 98(1):23-31. 
Bondia-Pons I, Savolainen O, Törrönen R, Martinez JA, Poutanen K, Hanhineva K (2014). Metabolic profiling of goji berry extracts for discrimination of geographical origin by non-targeted liquid chromatography coupled to quadrupole time-of-flight mass spectrometry. Food Research International 63 Part B:132-138.

Breme K, Guggenbühl B (2014). Aroma profile of a red-berries yoghurt drink by HS-SPME-GC-MS-O and influence of matrix texture on volatile aroma compound release of flavored dairy products. In: Flavour Science. Lopez VF (Ed) Academic Press, San Diego, pp 101-106.

Brinques GB, Ayub MZ (2011). Effect of microencapsulation on survival of Lactobacillus plantarum in simulated gastrointestinal conditions, refrigeration, and yogurt. Journal of Food Engineering 103(2):123-128.

Brudzynski K (2006). Effect of hydrogen peroxide on antibacterial activities of Canadian honeys. Canadian Journal of Microbiology 52(12):1228-1237.

Brudzynski K, Abubaker K, Miotto D (2012). Unraveling a mechanism of honey antibacterial action: Polyphenol/H2O2-induced oxidative effect on bacterial cell growth and on DNA degradation. Food Chemistry 133(2):329-336.

Brudzynski K, Kim L (2011). Storage-induced chemical changes in active components of honey de-regulate its antibacterial activity. Food Chemistry 126(3):1155-1163.

Bunea A, Rugină D, Sconța Z, Pop RM, Pintea A, Socaciu C, Tăbăran F, Grootaert C, Struijs K, Vancamp J (2013). Anthocyanin determination in blueberry extracts from various cultivars and their antiproliferative and apoptotic properties in B16-F10 metastatic murine melanoma cells. Phytochemistry 95:436-444.

Butel MJ (2014). Probiotics, gut microbiota and health. Médecine et Maladies Infectieuses 44(1):1-8.

Champagne CP, Green-Johnson J, Raymond Y, Barrette J, Buckley N (2009). Selection of probiotic bacteria for the fermentation of a soy beverage in combination with Streptococcus thermophilus. Food Research International 42(5-6):612-621.

Chavarri M, Maranon I, Ares R, Ibanez FC, Marzo F, Villaran MDC (2010). Microencapsulation of a probiotic and prebiotic in alginatechitosan capsules improves survival in simulated gastro-intestinal conditions. Int J Food Microbiol 142(1-2):185-189.

Chedea VS, Braicu C, Socaciu C (2010). Antioxidant/prooxidant activity of a polyphenolic grape seed extract. Food Chemistry 121(1):132-139.

Chookietwattana K (2014). Lactic acid production from simultaneous saccharification and fermentation of Cassava starch by Lactobacillus Plantarum MSUL 903. APCBEE Procedia 8:156-160.

Chouchouli V, Kalogeropoulos N, Konteles SJ, Karvela E, Makris DP, Karathanos VT (2013). Fortification of yoghurts with grape (Vitis vinifera) seed extracts. LWT-Food Science and Technology 53(2):522-529.

Coda R, Lanera A, Trani A, Gobbetti M, Di Cagno R (2012). Yogurtlike beverages made of a mixture of cereals, soy and grape must: Microbiology, texture, nutritional and sensory properties. International Journal of Food Microbiology 155(3):120-127.
Cruz AG, Cadena RS, Castro WF, Esmerino EA, Rodrigues JB, Gaze L, Faria JF, Freitas MQ, Deliza R, Bolini HMA (2013). Consumer perception of probiotic yogurt: Performance of check all that apply (CATA), projective mapping, sorting and intensity scale. Food Research International 54(1):601-610.

Cruz AG, Walter EHM, Cadena RS, Faria JF, Bolini HMA, Pinheiro HP, Sant'ana AS (2010). Survival analysis methodology to predict the shelf-life of probiotic flavored yogurt. Food Research International 43(5):1444-1448.

Davis C (2014). Enumeration of probiotic strains: Review of culturedependent and alternative techniques to quantify viable bacteria. Journal of Microbiological Methods 103:9-17.

de Oliveira MN (2014). Fermented milks-Fermented milks and yogurt. In: Encyclopedia of Food Microbiology (Second Edition). Tortorello CABL (Ed), Academic Press, Oxford pp 908-922.

do Espírito Santo AP, Perego P, Converti A, Oliveira MN (2011). Influence of food matrices on probiotic viability - A review focusing on the fruity bases. Trends in Food Science and Technology 22(7):377-385.

Donno D, Beccaro GL, Mellano MG, Cerutti AK, Bounous G (2014). Goji berry fruit (Lycium spp.): antioxidant compound fingerprint and bioactivity evaluation. Journal of Functional Foods doi:10.1016/j.jff.2014.05.020.

El-Said MM, Haggag HF, Fakhr El-Din HM, Gad AS, Farahat AM (2014). Antioxidant activities and physical properties of stirred yoghurt fortified with pomegranate peel extracts. Annals of Agricultural Sciences 59(2):207-212.

Goktepe I, Juneja VK, Ahmedna M (2006). Probiotics in food safety and human health, Taylor and Francis group, Boca Raton, Florida.

Guarner F, Schaafsma GJ (1998). Probiotics. International Journal of Food Microbiology 39(3):237-238.

How CW, Teruel JA, Ortiz A, Montenegro MF, Rodríguez-López JN, Aranda FJ (2014). Effects of a synthetic antitumoral catechin and its tyrosinase-processed product on the structural properties of phosphatidylcholine membranes. Biochimica et Biophysica Acta (BBA) - Biomembranes 1838(5):1215-1224.

Hunaefi D, Akumo DN, Riedel H, Smetanska I (2012). The effect of Lactobacillus plantarum ATCC 8014 and Lactobacillus acidophilus NCFM fermentation on antioxidant properties of selected in vitro sprout culture of Orthosiphon aristatus (java tea) as a model study. Antioxidants 1(1):4-32.

Inbaraj BS, Lu H, Kao TH, Chen BH (2010). Simultaneous determination of phenolic acids and flavonoids in Lycium barbarum Linnaeus by HPLC-DAD-ESI-MS. Journal of Pharmaceutical and Biomedical Analysis 51(3):549-556.

Jaziri I, Ben Slama M, Mhadhbi H, Urdaci MC, Hamdi M (2009). Effect of green and black teas (Camellia sinensis L.) on the characteristic microflora of yogurt during fermentation and refrigerated storage. Food Chemistry 112(3):614-620.

Jimborean MA, Țibulcă D (2013). Dairy Technology (in Romanian). Risoprint, Cluj-Napoca, $246 \mathrm{p}$.

Kailasapathy K, Harmstorf I, Phillips M (2008). Survival of Lactobacillus acidophilus and Bifidobacterium animalis ssp. lactis in stirred fruit 
202

yogurts. LWT-Food Science and Technology 41(7):1317-1322.

Karaaslan M, Ozden M, Vardin H, Turkoglu H (2011). Phenolic fortification of yogurt using grape and callus extracts. LWT-Food Science and Technology 44(4):1065-1072.

Kent RM, Doherty SB (2014). Probiotic bacteria in infant formula and follow-up formula: Microencapsulation using milk and pea proteins to improve microbiological quality. Food Research International 64:567-576.

Khalid K (2011). An overview of lactic acid bacteria. International Journal of Biosciences 1(3):1-13.

Krasaekoopt W, Bhandari B, Deeth H (2003). Evaluation of encapsulation techniques of probiotics for yoghurt. International Dairy Journal 13(1):3-13.

Liu Y, Cao L, Du J, Jia R, Wang J, Xu P, Yin G (2015). Protective effects of Lycium barbarum polysaccharides against carbon tetrachlorideinduced hepatotoxicity in precision-cut liver slices in vitro and in vivo in common carp (Cyprinus carpio L.). Comparative Biochemistry and Physiology Part C: Toxicology \& Pharmacology 169:65-72.

Lourens-Hattingh A, Viljoen BC (2001). Yogurt as probiotic carrier food. International Dairy Journal 11(1-2):1-17.

Martínez V, Mitjans M, Vinardell MP (2014). Cytoprotective effects of polyphenols against oxidative damage. In: Polyphenols in human health and disease, Watson RR, Preedy VR, Zibadi S (Eds), Academic Press, San Diego pp 275-288.

Medina MB (2011). Determination of the total phenolics in juices and superfruits by a novel chemical method. Journal of Functional Foods 3(2):79-87.

Michael M, Phebus RK, Schmidt KA (2010). Impact of a plant extract on the viability of Lactobacillus delbrueckii ssp. bulgaricus and Streptococcus thermophilus in nonfat yogurt. International Dairy Journal 20(10):665-672.

Ouwehand AC, Röytiö H (2015). Probiotic fermented foods and health promotion. In: Advances in fermented foods and beverages, Holzapfel W (Ed), Woodhead Publishing pp 3-22.

Perna A, Intaglietta I, Simonetti A, Gambacorta E (2014). Antioxidant activity of yogurt made from milk characterized by different casein haplotypes and fortified with chestnut and sulla honeys. Journal of Dairy Science 97(11):6662-6670.

Pintea A, Diehl HA, Momeu C, Aberle L, Socaciu C (2005). Incorporation of carotenoid esters into liposomes. Biophysical Chemistry 118(1):7-14.

Pintea A, Rugină DO, Pop R, Bunea A, Socaciu C (2011). Xanthophylls protect against induced oxidation in cultured human retinal pigment epithelial cells. Journal of Food Composition and Analysis 24(6):830-836.

Pinto SS, Fritzen-Freire CB, Munoz IB, Barreto PLM, Prudencio ES, Amboni RDMC (2012). Effects of the addition of microencapsulated Bifidobacterium BB-12 on the properties of frozen yogurt. Journal of Food Engineering 111(4):563-569.

Rastall RA, Maitin V (2002). Prebiotics and synbiotics: towards the next generation. Current Opinion in Biotechnology 13(5):490-496.

Rotar MA, Semeniuc C, Apostu S, Suharoschi R, Mureşan C, Modoran
C, Laslo C, Guş C, Culea M (2007). Researches concerning microbiological evolution of lactic acid bacteria to yoghurt storage during shelf-life. Journal of Agroalimentary Processes and Technologies 13(1):135-138.

Saint-Eve A, Lévy C, Martin N, Souchon I (2006). Influence of proteins on the perception of flavored stirred yogurts. Journal of Dairy Science 89(3):922-933.

Sanders ME (2003). Probiotics: considerations for human health. Nutrition Reviews 61:91-99.

Sanders ME, Akkermans LMA, Haller D, Hammerman C, Heimbach J, Hörmannsperger G, Huys G, Levy DD, Lutgendorff F, Mack D, Phothirath P, Solano-Aguilar G, Vaughan E (2010). Safety assessment of probiotics for human use. Gut Microbes 1(3):164 185.

Ścibisz I, Ziarno M, Mitek M, Zaręba D (2012). Effect of probiotic cultures on the stability of anthocyanins in blueberry yoghurts. LWT-Food Science and Technology 49(2):208-212.

Senaka Ranadheera C, Evans CA, Adams MC, Baines SK (2012). Probiotic viability and physico-chemical and sensory properties of plain and stirred fruit yogurts made from goat's milk. Food Chemistry 135(3):1411-1418.

Shiby VK, Mishra HN (2013). Fermented milks and milk products as functional foods-A review. Critical Reviews in Food Science and Nutrition 53(5):482-496.

Socaciu C, Jessel R, Diehl HA (2000). Competitive carotenoid and cholesterol incorporation into liposomes: effects on membrane phase transition, fluidity, polarity and anisotropy. Chemistry and Physics of Lipids 106(1):79-88.

Srinivasan K (2014). Polyphenols in vision and eye health. In: Handbook of nutrition, diet and the eye, Preedy VR (Ed), Academic Press, San Diego pp 413-421.

Stanton C, Gardiner G, Meehan H, Collins K, Fitzgerald G, Lynch PB, Ross RP (2001). Market potential for probiotics. Am J Clin Nutr 73(2):476s-483s.

Sun-Waterhouse D, Zhou J, Wadhwa SS (2013). Drinking yoghurts with berry polyphenols added before and after fermentation. Food Control 32(2):450-460.

Teitelbaum JE, Walker WA (2002). Nutritional impact of pre and probiotics as protective gastrointestinal organisms. Annual Review of Nutrition 22:107-138.

Tewari J, Irudayaraj J (2004). Quantification of saccharides in multiple floral honeys using fourier transform infrared microattenuated total reflectance spectroscopy. Journal of Agricultural and Food Chemistry 52(11):3237-3243.

Tseng A, Zhao Y (2013). Wine grape pomace as antioxidant dietary fibre for enhancing nutritional value and improving storability of yogurt and salad dressing. Food Chemistry 138(1):356-365.

Vinderola CG, Costa GA, Regenhardt S, Reinheimer JA (2002). Influence of compounds associated with fermented dairy products on the growth of lactic acid starter and probiotic bacteria. International Dairy Journal 12(7):579-589.

Vodnar DC, Socaciu C (2014). Selenium enriched green tea increase stability of Lactobacillus casei and Lactobacillus plantarum in chitosan coated alginate microcapsules during exposure to simulated 
gastrointestinal and refrigerated conditions. LWT-Food Science and Technology 57(1):406-411.

Voidarou C, Alexopoulos A, Plessas S, Karapanou A, Mantzourani I, Stavropoulou E, Fotou K, Tzora A, Skoufos I, Bezirtzoglou E (2011). Antibacterial activity of different honeys against pathogenic bacteria. Anaerobe 17(6):375-379.

Wang CC, Chang SC, Inbaraj BS, Chen BH (2010). Isolation of carotenoids, flavonoids and polysaccharides from Lycium barbarum L. and evaluation of antioxidant activity. Food Chemistry 120(1):184-192.

Wang Y (2009). Prebiotics: Present and future in food science and technology. Food Research International 42(1):8-12.

Xiao J, Liong EC, Ching YP, Chang RCC, So KF, Fung ML, Tipoe GL (2012). Lycium barbarum polysaccharides protect mice liver from carbon tetrachloride-induced oxidative stress and necroinflammation. Journal of Ethnopharmacology 139(2):462-470.
Yang X, Bai H, Cai W, Li J, Zhou Q, Wang Y, Han J, Zhu X, Dong M, Hu D (2013). Lycium barbarum polysaccharides reduce intestinal ischemia/reperfusion injuries in rats. Chemico-Biological Interactions 204(3):166-172.

Ye M, Liu D, Zhang R, Yang L, Wang J (2012). Effect of hawk tea (Litsea coreana $\mathrm{L}$.) on the numbers of lactic acid bacteria and flavour compounds of yoghurt. International Dairy Journal 23(1):68-71.

Zalibera M, Staško A, Šlebodová A, Jančovičová V, Čermáková T, Brezová V (2008). Antioxidant and radical-scavenging activities of Slovak honeys - An electron paramagnetic resonance study. Food Chemistry 110(2):512-521.

Zamfir M, Vancanneyt M, Makras L, Vaningelgem F, Lefebvre K, Pot B, Swings J, de Vuyst L (2006). Biodiversity of lactic acid bacteria in Romanian dairy products. Systematic and Applied Microbiology 29(6):487-495. 